\title{
Propagation of the Storegga tsunami into ice-free lakes along the southern shores of the Barents Sea
}

\author{
Anders Romundset ${ }^{a,{ }^{*}}$ - anders.romundset@uit.no \\ Stein Bondevik ${ }^{\mathrm{a}, \mathrm{b}}$ - stein.bondevik@hisf.no \\ a Department of Geology, University of Tromsø, Dramsvegen 201, NO-9037 Tromsø, Norway \\ ${ }^{\mathrm{b}}$ Sogn og Fjordane University College, Postboks 133, NO-6851 Sogndal, Norway \\ * Correspondence to: Anders Romundset, Department of Geology, University of Tromsø, \\ Dramsvegen 201, NO-9037 Tromsø, Norway. Telephone: (47) 776462 06, E-mail: \\ anders.romundset@uit.no
}

\begin{abstract}
There is clear evidence that the Storegga tsunami, triggered by the giant Storegga slide offshore western Norway 8100-8200 years ago, propagated into the Barents Sea. Cores from five coastal lakes along the coast of Finnmark in northern Norway reveal major erosion and deposition from the inundation of the tsunami. The deposits rest on a distinct erosional unconformity and consist of graded sand layers and re-deposited organic remains. Some of the organic remains are rip-up clasts of lake mud, peat and soil and suggest strong erosion of the lake floor and neighbouring land. In this part of the Arctic coastal lakes are usually covered by $>1 \mathrm{~m}$ of solid lake ice in the winter season. The significant erosion and deposition of rip-up clasts indicate that the lakes were ice free and that the ground was probably not frozen. We suggest that the Storegga slide and tsunami event happened sometime in the summer season; between April and October. Minimum run-up has been reconstructed to 3-4 $\mathrm{m}$.
\end{abstract}

KEYWORDS: Storegga; Tsunami deposits; Finnmark; Barents Sea; Holocene;

\section{Introduction}

The giant submarine Storegga slide (Fig. 1A) triggered a widespread tsunami in the North Atlantic some 8100-8200 years ago. Associated tsunami deposits have, during the last two decades, been discovered at numerous sites; the Norwegian coast (Bondevik et al. 1997a), Scotland (Dawson and Smith 2000; Smith et al. 2004), Shetland (Bondevik et al. 2003, 2005a), the Faroe Islands (Grauert et al. 2001) and at the east coast of Greenland (Wagner et al. 2006). Here we present evidence of tsunami deposits of Storegga age preserved in coastal 
lake deposits along the northernmost coast of Norway. This demonstrates that the Storegga tsunami propagated into the Barents Sea.

Storegga tsunami deposits were found in five coastal lakes. Coastal lakes below the marine limit are common along the Norwegian coast and record both sea-level changes and extreme oceanic events like tsunamis (Kjemperud 1986; Bondevik et al. 1998). We cored in all 18 such lakes from the lake ice in March/April of 2007 and 2008. Five of the lakes - situated from 0 to $3 \mathrm{~m}$ above the 8000 year shore line - hold tsunami deposits; one lake at Sørøya, three lakes at Rolvsøya and one lake at Nordkinn (Fig. 1B).

The Storegga tsunami event was probably cataclysmic to human stone-age cultures living close to sea level (Bondevik 2003). However, the scope of destruction must have been season-dependent; recovery after an impact during winter would likely be more strenuous than if it occurred in the summer, particularly in subarctic areas such as northern Norway. From the pattern of erosion and deposition we deduce that the deposits were laid down in icefree lakes; thus most likely the Storegga Slide and tsunami occurred during the summer season. The details of relative sea-level changes at the localities, some of which are referred to below, are given in a parallel paper (Paper II: Romundset et al.).

\section{Methods}

Sediment cores were retrieved using both Russian and piston corers (Jowsey 1966; Nesje 1992). The cores were photographed and carefully described in the laboratory. The physical attributes of tsunami deposits in lake basins make them, in most cases, easy to discern from the background mud, and also from possible storm deposits (Bondevik et al. 1997b; Morton et al. 2007). Descriptions include grain size and sorting of the sand layers, visual sediment characteristics and macrofossil content of clasts. X-ray radiographs help to identify internal structures, including sand coating of some rip-up clasts. Terrestrial plant remains were picked from just above and within the deposits (Table 1) and radiocarbon dated at the National Laboratory for ${ }^{14} \mathrm{C}$ dating in Trondheim. The resulting ages aid correlation of the tsunami deposits to the Storegga Slide. The ages were calibrated using OxCal v4.1 (Bronk Ramsey 2009), with the Intcal09 dataset (Reimer et al. 2009), and are reported with $2 \sigma$ confidence 
intervals. All basins except for the one at Sørøya have bedrock sills that were levelled from benchmarks.

\section{Results}

The tsunami deposits in the five lakes are described below. Sea level at the time of the Storegga slide has been reconstructed to $5 \mathrm{~m}$ a.s.1. at Rolvsøya, $11 \mathrm{~m}$ at Sørøya and 11-12 m at Nordkinn (Paper II: Romundset et al.). Details of the deposits in the three lakes at Rolvsøya are shown in Figs. 2, 3 and 4. A fourth lake at $12.5 \mathrm{~m}$ a.s.1. at Rolvsøya was also cored, but is only $20-30 \mathrm{~cm}$ deep with almost no sediments.

\section{Lake 5, Rolvsøya (a few dm above Storegga sea level)}

Lake 5 (Fig. 2A, 2B) was situated a few decimetres (Paper II: Romundset et al.) above the shoreline when the tsunami hit the coast and show deep erosion and deposition of sand and gravel. We traced a sand/gravel layer, 5-15 cm thick, which rests upon an erosive boundary and fines upwards from gravel to medium-grained sand, in four cores along a ca. $300 \mathrm{~m}$ long transect of the lake (Fig. 2C, D). The erosive contact cuts deep into the basin deposits especially around the central part of the lake where the outlet of the lake is located. Here the tsunami removed more than 3000 year of accumulated sediments (Fig. 2D). The basin was isolated from the sea $11,180-10,770 \mathrm{yr}$ BP. This transition is marked by a distinct blackish laminated deposit, called the isolation contact (Kjemperud 1986). These characteristic deposits are missing in core 5R-3 and 5R-4, barely preserved in 5R-5 and preserved in 5R-6 (Fig. 2C, 2D).

In some of the cores rip-up clasts of organic material in a matrix of sand and detritus is on top of the sand layer (Fig. 2D). Such rip-up clasts of lake mud (gyttja) and peat are well known from Storegga tsunami deposits in lakes and have been named 'organic conglomerate' (Bondevik et al. 1997b). The clasts are randomly orientated and vary in size from $1 \mathrm{~cm}$ to more than the core diameter of $11 \mathrm{~cm}$. We analysed the fragments $>0.250 \mathrm{~mm}$ and found that the light brown clasts of homogenous texture contain remains from limnic animals and plants, e.g. large numbers of Chironomidae larvae head capsules, Daphnia pulex ephippia, Trichoptera tubes and various bryozoans. These are thus clasts of lake mud eroded from the 
lake floor. The reddish-brown clasts are composed of moss roots, and are from a peat, probably eroded from the rim of the lake or the peaty terrain surrounding the lakes.

Fragments of moss and leaves found at the top of the organic conglomerate were dated to $8420-8200 \mathrm{yr}$ BP. These plant remains were washed from the watershed and re-deposited at the lake bottom by the tsunami wave, hence the age which is slightly older than the Storegga slide.

\section{Lake 6, Rolvsøya (ca. $1 \mathrm{~m}$ above Storegga sea level)}

This lake was also isolated ca. 3000 years prior to the tsunami, but here erosion did not reach the isolation boundary (Figs. 2C, D). Closest to the outlet, in core 6-1 (Fig. 2C) we found a ca. $5 \mathrm{~cm}$ thick sand layer, fining upwards from very coarse - medium sand and resting on an erosional unconformity. Enclosed in the sand is a disc-shaped boulder (long axis $=10.5 \mathrm{~cm}$ ), possibly a so-called tsunami-ishi (Kato and Kimura 1983; MacInnes et al. 2009a) that must have been moved from the nearshore into the lake by the Storegga tsunami and subsequently became rotated during coring operation. A Salix leaf and some other terrestrial plant remains picked from the gyttja 2-3 cm above this deposit yielded 7920-7670 yr BP. Another core, core 6R-1 (Figs. 2C, D \& 3B) was taken about $50 \mathrm{~m}$ further away from the lake outlet and holds a similar sequence, but with only ca. $1 \mathrm{~cm}$ of sand followed by a ca. $35 \mathrm{~cm}$ thick unit of 'organic conglomerate' holding both gyttja clasts, scattered sand and dark reddish-brown peat clasts.

\section{Lake 7, Rolvsøya (ca. 3 m above tsunami sea level)}

A ca. $20 \mathrm{~cm}$ thick tsunami unit here comprises clasts of gyttja and soil and is concluded by a 1-2 cm thick sand layer. Many of the clasts are coated by a veneer of sand (Fig. 4A, B), probably because they were rolled within a turbid, sediment-laden current. Terrestrial plant remains from just above this sand were dated to $8190-8000 \mathrm{yr}$ BP. Unfortunately, compact sediments in this lake prevented penetration other than with the piston corer at one site.

\section{Lake 4, Sørøya (only few dm above tsunami sea level)}

Similar to Lake 5, this basin became inundated by the tsunami shortly before it was transgressed (see Fig. 6 in Paper II: Romundset et al.). The tsunami deposit rests on a distinct erosional unconformity above marine silt and comprises about $19 \mathrm{~cm}$ of gravel and sand, including stones with diameter $>2 \mathrm{~cm}$, followed by about $5 \mathrm{~cm}$ of light-grey silt clasts. In the 
latter, remains of Hydroidea and foraminifera were found. Brown gyttja continues above the tsunami deposit, and a small twig found at this boundary was dated to $8310-8020 \mathrm{yr} \mathrm{BP}$.

\section{Lake 15, Nordkinn peninsula (1-2 $m$ above tsunami sea level)}

The easternmost lake was isolated ca 1500 years before Storegga time (see Paper II: Romundset et al.; log in Fig. 8C, photograph b and radiograph c in Fig. 8F.). Coarse organic remains and some pebbles (3-4 cm diametre) rest on an erosional unconformity and are followed by a mixture of gyttja clasts and silty, heterogeneous mud. The unit is in total about $50 \mathrm{~cm}$ long and the mud holds a mixed assemblage of subfossils from both limnic organisms (e.g. Daphnia, ?Centropyxis and Chironomidae) and marine organisms such as Hydroidea and Pectinaria, showing that marine silt was washed into the lake by the tsunami. A twig picked from the lower part of the unit was dated to $8580-8390 \mathrm{yr} \mathrm{BP}$, and is assumed to have been eroded from the watershed and deposited into the lake by the Storegga tsunami.

\section{Discussion}

\subsection{Northward propagation and local run-up of the Storegga tsunami}

Motivated by finds of presumed tsunami deposits in western Norway (Svendsen and Mangerud 1990), Harbitz (1992) proposed a model for tsunamis generated by the Storegga slide that indicates propagation northwards along the entire Norwegian coastline and into the Barents Sea area. Deposits from the tsunami were later documented and described from many near-shore basins in western and central Norway by Bondevik et al. (1997a). They also reevaluated previously published works, and suggested that in many cases, traces left by the Storegga tsunami had erroneously been interpreted as results of marine inundation during the mid-Holocene transgression (Bondevik et al. 1998). This included a study from Troms in northern Norway (Fig. 1A), where later field work has confirmed the assumption and run-up to 4-6 $\mathrm{m}$ has been reconstructed (Rasmussen and Bondevik, unpubl. data). Tsunamis have very long wavelengths and can travel huge distances without being much influenced by topography. This explains the impact at the Finnmark coast, $\sim 1300 \mathrm{~km}$ away from the slide, as well as in Northeast Greenland (Wagner et al. 2006). It is also likely that the tsunami propagated well beyond these localities - especially in Finnmark were run-up is $>3 \mathrm{~m}$. 
Tsunami deposits in Lake 7 reveal run-up ca. $3 \mathrm{~m}$ above reconstructed mean-tide sea level at the time. The difference between highest and lowest astronomically-forced tide in the region is ca. $320 \mathrm{~cm}$ (NHS 2010); thus it is possible that run-up was $\sim 1.5 \mathrm{~m}$ lower or higher.

However, the sand-coated rip-up clasts indicate that relatively high energy was involved, which would suggest that run-up was higher. At Nordkinn we investigated a lake at $18.18 \pm 0.10 \mathrm{~m}$ a.s.1. that did not contain any traces of a tsunami, suggesting that run-up here was less than $5 \mathrm{~m}$.

\subsection{Inundation into ice free lakes?}

Mean winter temperatures at the localities in coastal Finnmark are presently around $-2^{\circ} \mathrm{C}$ to $4^{\circ} \mathrm{C}$ (DNMI 2010). Lake ice typically forms in October and breaks up in May. More than a metre thick ice covered the lakes during our field work in March-April, both in 2007 and 2008. Furthermore, the age of green mosses that became buried alive by the Storegga tsunami (Bondevik et al. 2006; Weninger et al. 2008) shows striking correspondence to the coldest spike of the NGRIP oxygen isotope curve during the " 8.2 event" (Thomas et al. 2007). Thus winter temperatures at the time in Finnmark were probably considerably lower than at present, with lakes being frozen for at least as long periods during winter.

It has previously been suggested that the Storegga tsunami occurred in late autumn, based on findings of certain plant and animal macrofossils (Bondevik et al. 1997a; Dawson and Smith 2000). However, such remains are likely to have been re-deposited by the tsunami, which indeed eroded into both terrestrial and marine deposits. However, the deep erosion into the lake deposits and inland fining of the sand in the lakes in Finnmark, as well as the occurrence of rip-up peat and soil clasts, show that the tsunami must have hit ice-free lakes and unfrozen ground. That would mean that the event happened sometime between April and October.

The sand deposited by the tsunami ranges from sorted gravel at a site near the outlet in Lake 5 to medium sand in Lake 7 (Fig. 2C, D). Also, there is a clear pattern of more erosion closer to the shoreline. These attributes indicate that more energy was involved near the shore. If sediments would have been deposited on ice-covered lakes, re-deposition after ice break-up would not result in the observed pattern of erosion and sorting. The lake ice and the frozen, snow covered ground would minimise erosion by the turbid tsunami current (Minoura et al. 1996; MacInnes et al. 2009a, 2009b). 


\subsection{Did other Holocene tsunamis hit the coast of Finnmark?}

Catastrophic, submarine mass movement events have had a great influence on the morphology of the Norwegian-Svalbard margin (e.g. Haflidason et al. 2004). Several other slide scars and deposits have been mapped in addition to the Storegga slide, of which two are believed to have taken place during the Holocene; the Trænadjupet slide with an inferred age of ca. 4500 years, and the undated Andøya slide (Fig. 1A; Laberg and Vorren 2000; Laberg et al. 2000, 2002). In Finnmark, several basins have been cored that have remained close to sea level since Storegga times, but no other signs of influence from the ocean were found. We therefore find it unlikely that tsunamis younger than the Storegga have inundated the coast of Finnmark. The volume and velocity of the slide material determines its potential to generate a tsunami, seemingly neither the Trænadjupet nor the Andøya slides produced widespread tsunamis.

\section{Conclusions}

- The Storegga tsunami entered the Barents Sea and hit the coast of Finnmark.

- The event likely happened during the summer season, sometime between April and October.

- No other tsunamis have left traceable deposits in this part of the Norwegian coast during the Holocene.

Acknowledgements. We much appreciate the field assistance by Ingvar Nørstegård Tveiten,

Kristian Lindem and Hilary Dugan. Radiocarbon dating was done at the National Laboratory for ${ }^{14} \mathrm{C}$-dating in Trondheim. Financial support for radiocarbon dating from the SPONCOM programme at the University of Tromsø and the Roald Amundsen Centre for Arctic Research.

\section{References}

Bondevik, S. 2003. Storegga tsunami sand in peat below the Tapes beach ridge at Harøy, western Norway, and its possible relation to an early Stone Age settlement. Boreas 32, 476-483. 
Bondevik, S., Løvholt, F., Harbitz, C. B., Stormo, S. and Skjerdal, G. 2006. The Storegga slide tsunami - deposits, run-up heights and radiocarbon dating of the 8000-year-old tsunami in the North Atlantic. American Geophysical Union, Fall Meeting 2006, abstract \#OS34C-01. 87.

Bondevik, S., Mangerud, J., Dawson, S., Dawson, A. and Lohne, Ø. 2005a. Evidence for three North Sea tsunamis at the Shetland Islands between 8000 and 1500 years ago. Quaternary Science Reviews 24 (14-15), 1757-1775.

Bondevik, S., Mangerud, J., Dawson, S., Dawson, A. G. and Lohne, Ø. S. 2003. Record-breaking height for 8000-year-old tsunami in the North Atlantic. EOS 84, 289-293.

Bondevik, S., Svendsen, J. I., Johnsen, G., Mangerud, J. and Kaland, P. E. 1997a. The Storegga tsunami along the Norwegian coast, its age and runup. Boreas 26 (1), 29-53.

Bondevik, S., Svendsen, J. I. and Mangerud, J. 1997b. Tsunami sedimentary facies deposited by the Storegga tsunami in shallow marine basins and coastal lakes, western Norway. Sedimentology 44 (6), 1115-1131.

Bondevik, S., Svendsen, J. I. and Mangerud, J. 1998. Distinction between the Storegga tsunami and the Holocene marine transgression in coastal basin deposits of western Norway. Journal of Quaternary Science 13, 529-537.

Bronk Ramsey, C. 2009. Bayesian analysis of radiocarbon dates. Radiocarbon 51 (1), 337-360.

Dawson, S. and Smith, D. E. 2000. The sedimentology of middle Holocene tsunami facies in northern Sutherland, Scotland. Marine Geology 170, 69-79.

DNMI. 2010. "eKlima." Norwegian Meteorological Institute Retrieved January, 2008, from http:eklima.met.no.

Grauert, M., Bjorck, S. and Bondevik, S. 2001. Storegga tsunami deposits in a coastal lake on Suouroy, the Faroe Islands. Boreas 30 (4), 263-271.

Hafliðason, H., Lien, R., Sejrup, H. P., Forsberg, C. F. and Bryn, P. 2005. The dating and morphometry of the Storegga Slide. Marine and Petroleum Geology 22 (1-2), 123-136.

Haflidason, H., Sejrup, H. P., Nygard, A., Mienert, J., Bryn, P., Lien, R., Forsberg, C. F., Berg, K. and Masson, D. 2004. The Storegga Slide: architecture, geometry and slide development. Marine Geology 213 (1-4), 201-234.

Harbitz, C. B. 1992. Model simulations of tsunamis generated by the Storegga slides. Marine Geology $105(1-4), 1-21$.

Jowsey, P. C. 1966. An improved peat sampler. New Phytologist 65 (2), 245-\&.

Kato, Y. and Kimura, M. 1983. Age and origin of so-called "Tsunami-ishi", Ishigaki Island, Okinawa Prefecture. The Journal of the Geological Society of Japan 89, 471-474.

Kjemperud, A. 1986. Late Weichselian and Holocene shoreline displacement in the Trondheimsfjord area, Central Norway. Boreas 15 (1), 61-82.

Laberg, J. S. and Vorren, T. O. 2000. The Trænadjupet Slide, offshore Norway - morphology, evacuation and triggering mechanisms. Marine Geology 171 (1-4), 95-114.

Laberg, J. S., Vorren, T. O., Dowdeswell, J. A., Kenyon, N. H. and Taylor, J. 2000. The Andøya Slide and the Andøya Canyon, north-eastern Norwegian-Greenland Sea. Marine Geology 162 (2-4), 259-275.

Laberg, J. S., Vorren, T. O., Mienert, J., Bryn, P. and Lien, R. 2002. The Trænadjupet Slide: a large slope failure affecting the continental margin of Norway 4,000 years ago. Geo-Marine Letters $22(1), 19-24$.

MacInnes, B. T., Bourgeois, J., Pinegina, T. K. and Kravchunovskaya, E. A. 2009b. Tsunami geomorphology: Erosion and deposition from the 15 November 2006 Kuril Island tsunami. Geology 37 (11), 995-998.

MacInnes, B. T., Pinegina, T. K., Bourgeois, J., Razhigaeva, N. G., Kaistrenko, V. M. and Kravchunovskaya, E. A. 2009a. Field survey and geological effects of the 15 November 2006 Kuril tsunami in the Middle Kuril Islands. Pure and Applied Geophysics 166 (1-2), 9-36.

Minoura, K., Gusiakov, V. G., Kurbatov, A., Takeuti, S., Svendsen, J. I., Bondevik, S. and Oda, T. 1996. Tsunami sedimentation associated with the 1923 Kamchatka earthquake. Sedimentary Geology 106 (1-2), 145-154. 
Morton, R. A., Gelfenbaum, G. and Jaffe, B. E. 2007. Physical criteria for distinguishing sandy tsunami and storm deposits using modem examples. Sedimentary Geology 200 (3-4), 184207.

Nesje, A. 1992. A piston corer for lacustrine and marine sediments. Arctic and Alpine Research 24 (3), 257-259.

NHS. 2010. "Norwegian tidal and sea level data." Norwegian Hydrographic Service Retrieved April, 2010, from http://vannstand.statkart.no/Engelsk/stat.php.

Reimer, P. J., Baillie, M. G. L., Bard, E., Bayliss, A., Beck, J. W., Blackwell, P. G., Bronk Ramsey, C., Buck, C. E., Burr, G. S., Edwards, R. L., Friedrich, M., Grootes, P. M., Guilderson, T. P., Hajdas, I., Heaton, T. J., Hogg, A. G., Hughen, K. A., Kaiser, K. F., Kromer, B., McCormac, F. G., Manning, S. W., Reimer, R. W., Richards, D. A., Southon, J. R., Talamo, S., Turney, C. S. M., Van der Plicht, J. and Weyhenmeyer, C. E. 2009. Intcal09 and Marine09 radiocarbon age calibration curves, 0-50,000 years BP. Radiocarbon 51 (4), 1111-1150.

Smith, D. E., Shi, S., Cullingford, R. A., Dawson, A. G., Dawson, S., Firth, C. R., Foster, I. D. L., Fretwell, P. T., Haggart, B. A., Holloway, L. K. and Long, D. 2004. The Holocene Storegga Slide tsunami in the United Kingdom. Quaternary Science Reviews 23 (23-24), 2291-2321.

Svendsen, J. I. and Mangerud, J. 1990. Sea-level changes and pollen stratigraphy on the outer coast of Sunnmøre, western Norway. Norsk Geologisk Tidsskrift 70 (2), 111-134.

Thomas, E. R., Wolff, E. W., Mulvaney, R., Steffensen, J. P., Johnsen, S. J., Arrowsmith, C., White, J. W. C., Vaughn, B. and Popp, T. 2007. The 8.2 ka event from Greenland ice cores. Quaternary Science Reviews 26 (1-2), 70-81.

Wagner, B., Bennike, O., Klug, M. and Cremer, H. 2006. First indication of Storegga tsunami deposits from East Greenland. Journal of Quaternary Science 22, 321-325.

Weninger, B., Schulting, R., Bradtmöller, M., Clare, L., Collard, M., Edinborough, K., Hilpert, J., Jöris, O., Niekus, M., Rohling, E. J. and Wagner, B. 2008. The catastrophic final flooding of Doggerland by the Storegga Slide tsunami. Documenta Praehistorica XXXV, 1-24. 

Table 1. Radiocarbon ages obtained on terrestrial plant fragments from within, or just above, the inferred tsunami deposits. The ages have been calibrated with OxCal v4.1 (Bronk Ramsey 2009), using the Intcal09 dataset (Reimer et al. 2009) and rounded off to nearest ten. The weighted average is calculated for the probability distribution of the calibrated age. All samples were submitted to the National Laboratory for ${ }^{14} \mathrm{C}$ dating in Trondheim, and AMS-measurements were performed at the radiocarbon dating laboratory in Uppsala (TUa-numbers).

\begin{tabular}{|c|c|c|c|c|c|c|c|c|c|c|c|}
\hline $\begin{array}{l}\text { Laboratory } \\
\text { number }\end{array}$ & Locality & Lake basin & Core & $\begin{array}{l}\text { Depth } \\
(\mathrm{cm})\end{array}$ & $\begin{array}{l}\text { Relation to } \\
\text { tsunami } \\
\text { deposit }\end{array}$ & Material dated & $\begin{array}{l}\text { Weight of } \\
\text { submitted } \\
\text { sample (mg) }\end{array}$ & $\begin{array}{l}{ }^{14} \mathrm{C} \text { age (yr } \\
\text { BP) }\end{array}$ & $\begin{array}{l}\text { Calibrated } \\
\text { age (yr BP, } \\
2 \sigma \text { interval) }\end{array}$ & $\begin{array}{l}\text { Weighted } \\
\text { average } \\
(\mu)\end{array}$ & $\begin{array}{l}\delta^{13} \mathrm{C} \\
(\% 0 \\
\mathrm{PDB})\end{array}$ \\
\hline TUa-7421 & Rolvsøya & Storvatnet & $5 \mathrm{R}-3$ & 781 & Within & Drepanocladus leaved & 13.2 & $7527 \pm 54$ & $8420-8200$ & 8330 & -27.6 \\
\hline TUa-7422 & Rolvsøya & Lillerundvatnet & $6-1$ & 420 & Just above & Salix leaf, flower bud, & 11 & & 670 & 7760 & -28.7 \\
\hline TUa-7423 & Rolvsøya & Badevatnet & $7-1$ & 340 & Just above & $\begin{array}{l}\text { Betula leaves, piece of } \\
\text { thin bark, moss stem }\end{array}$ & 100.1 & $7298 \pm 47$ & $8190-8000$ & 8100 & -31.8 \\
\hline TUa-7105 & Sørøya & Lillevatnet & $4 \mathrm{R}-2$ & 549 & Just above & Ericaceae twig & 45.2 & $7347 \pm 40$ & $8310-8020$ & 8150 & -27.2 \\
\hline TUa-7424 & Nordkinn & Kifjorddammen & $15-1$ & 254 & Within & Small twig & 39.1 & $7686 \pm 48$ & $8580-8390$ & 8480 & -28.9 \\
\hline
\end{tabular}




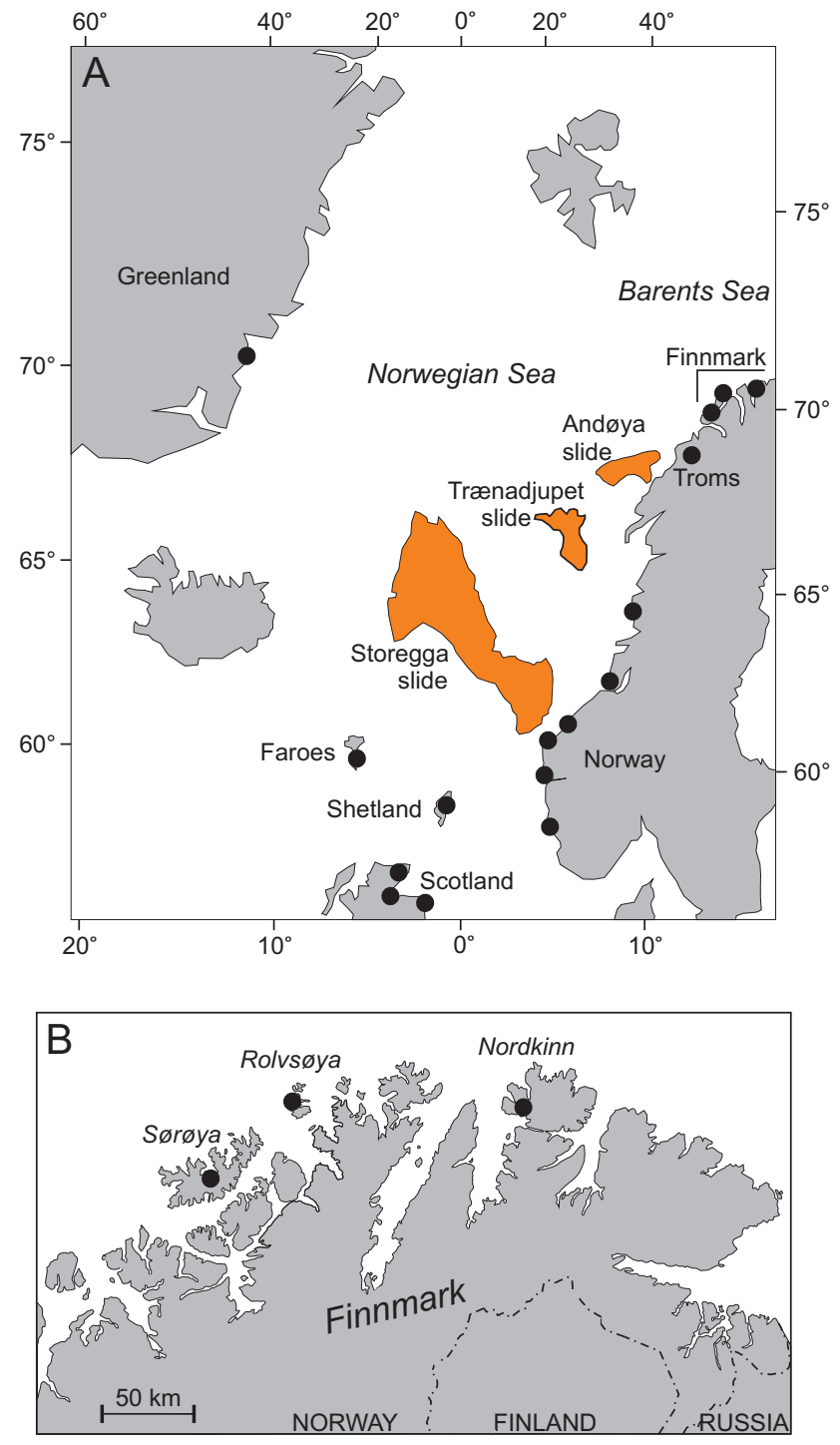

Figure 1. A. The land bordering the North Sea and Norwegian Sea with locations of Storegga tsunami deposits. Large slides of Holocene age are marked; the Storegga Slide happened around 8100-8200 years ago and had an estimated volume of 3000 $\mathrm{km}^{3}$ (Hafliðason et al. 2005), the Trænadjupet slide occurred ca. 4500 years ago and had a volume of $900 \mathrm{~km}^{3}$ (Laberg and Vorren 2000; Laberg et al. 2002) and the Andøya slide of unknown, but likely Holocene age (Laberg et al. 2000). So far only the Storegga slide is known to have generated a tsunami that has left deposits onshore. B. The coast of Finnmark county, northern Norway. Investigated lakes with tsunami deposits of Storegga age are found at Sørøya, Rolvsøya and Nordkinn. 



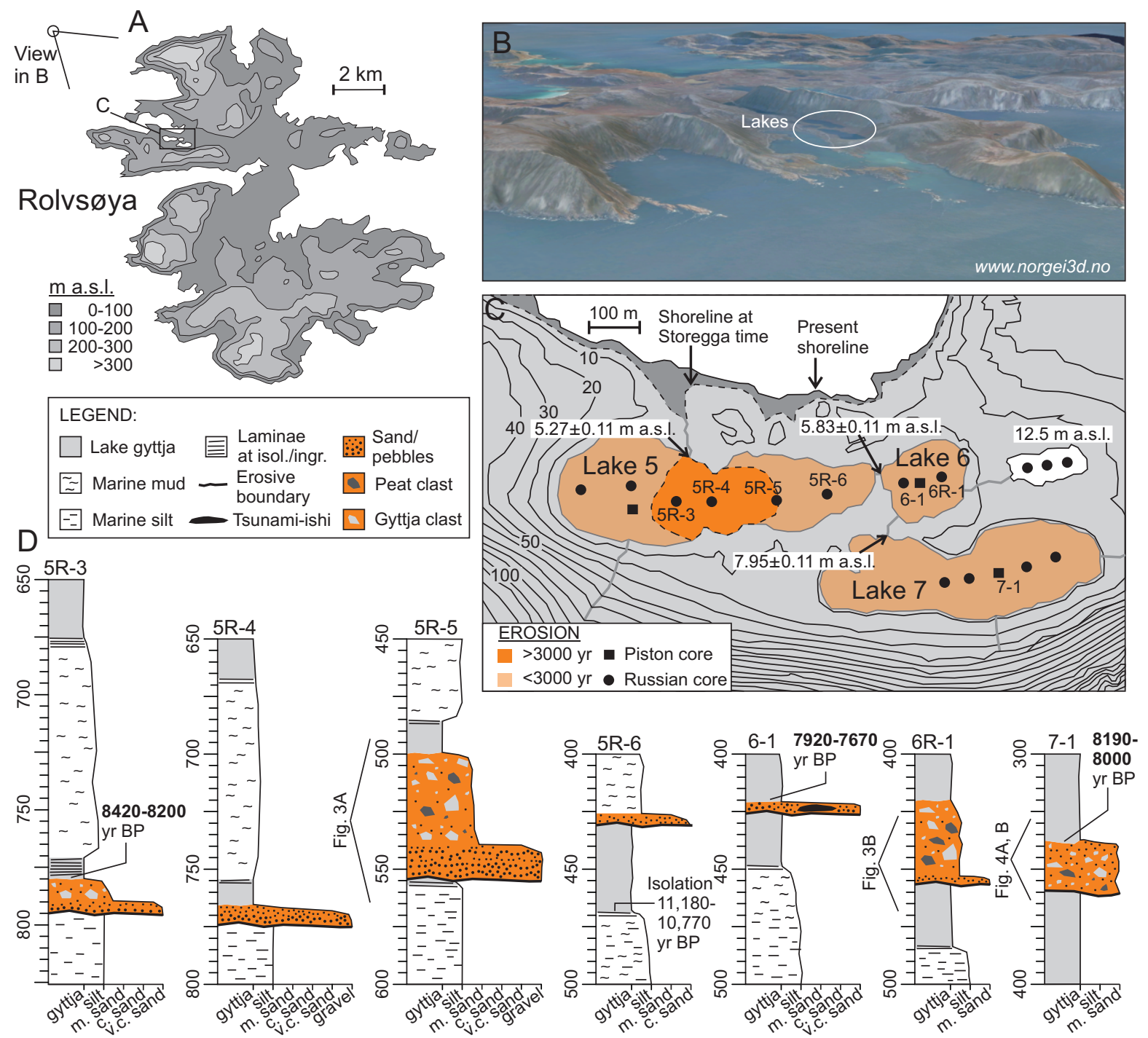

Figure 2. A. The island Rolvsøya, where three of the five described lakes are situated. The study area is marked. B. Oblique-view terrain model of Rolvsøya, illustrating the local setting of the investigated lakes. C. Map of lakes and core sites. Note that the lake at $12.5 \mathrm{~m}$ a.s.1. is only $20-$ $30 \mathrm{~cm}$ deep and has almost no sediments. D. Stratigraphic logs from three lakes at Rolvsøya. 


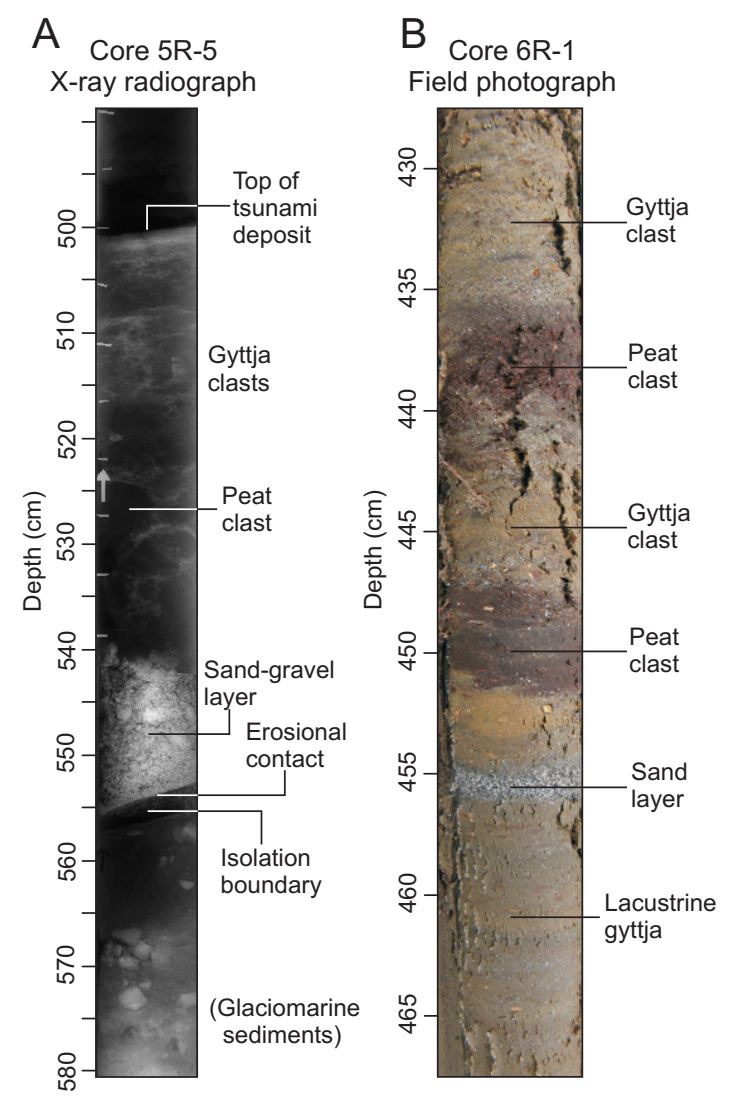

Figure 3. A. Radiograph of tsunami deposits in core sample 5R-5 (Fig. 2C). The erosional contact rests on laminated sediments that were deposited during lake isolation ca. $3000 \mathrm{yr}$ before the tsunami event. Above is a ca. $12-15 \mathrm{~cm}$ thick sand layer followed by rip-up clasts (organic conglomerate). B. Photograph of the tsunami deposit in core 6R-1 (Fig. 2C) shows a number of organic clasts. From below the tsunami deposit starts with a 1-2 $\mathrm{cm}$ thick sand layer resting upon gyttja and is followed by re-deposited organic clasts that continue up to $425 \mathrm{~cm}$ (above the frame). 


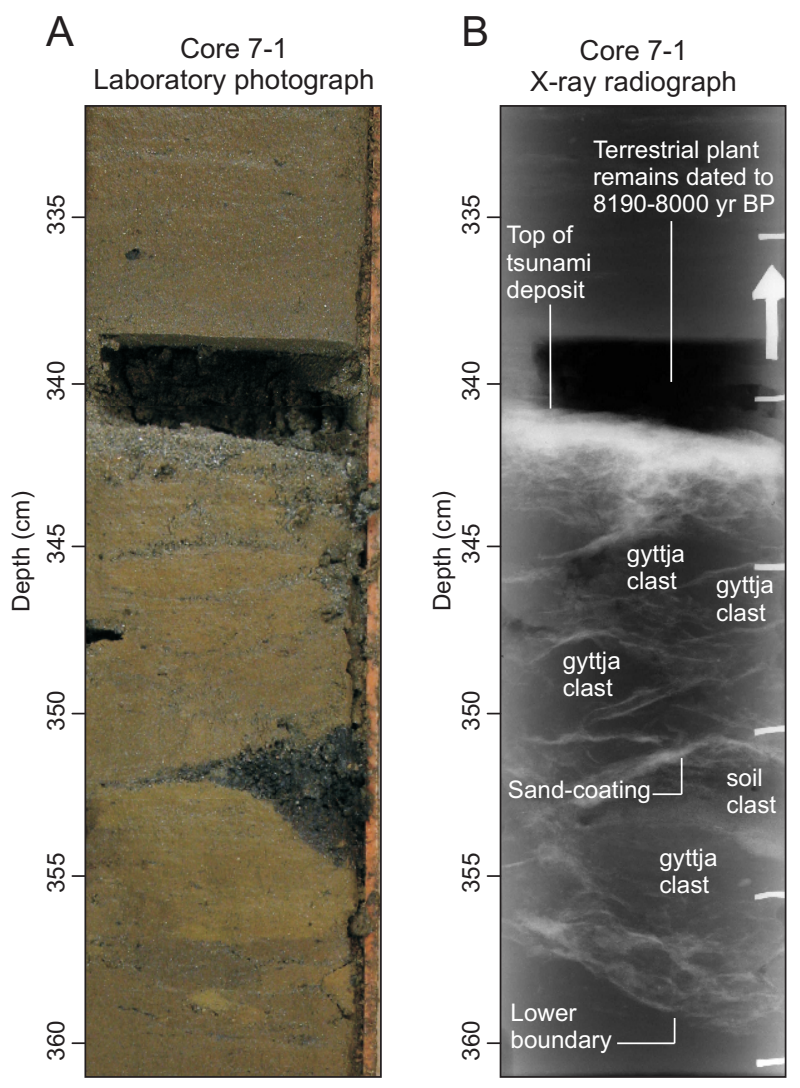

Figure 4. A. Photograph of the tsunami deposit in Lake 7 where various clasts of gyttja and soil occur in a ca. $15 \mathrm{~cm}$ thick unit. B. Radiograph of the same segment, where sand coating the gyttja clasts is clearly visible. The sand is attached to the clasts as they are dragged and rolled within the turbid tsunami current. 